\title{
Société Canadienne d'Études de la Renaissance/Canadian Society for Renaissance Studies
}

Annual Meeting of the Canadian Society for Renaissance Studies/Société des Études de la Renaissance (University of Western Ontario, London, Ontario, May $23-25,1978)$

At the time this material went to press (ca. March 1st) several speakers had, understandably, not yet been settled. A complete programme will be sent out to all of the Society's members in good time. All sessions will include speakers in French and English.

May 23, morning. Welcome to members. SESSION I (2-1/2 - 3 hrs.): RENAISSANCE ITALY (Chairman: Julius A. Molinaro, Italian Studies, University of Toronto). Speakers will include, A. Parel (Calgary), J. Brink (University of British Columbia), O. Pugliese (Toronto) and W. Melczer (Syracuse).

May 23, afternoon. SESSION II (2-1/2 - 3 hrs.): LA POÉSIE FRANÇAISE ET ANGLAISE AU 16e SIÈCLE (Chairman: André Berthiaume, Faculté des Lettres, Université Laval, Québec; assisted, for the paper on English poetry, by W.R. Gair, Department of English, University of New Brunswick, Fredericton). Speakers still to be arranged. The papers on English poetry should be illuminating to our Francophone colleagues and vice versa.

May 23, evening. RESEARCH PROJECTS AND LOCAL INSTITUTES AND SOCIETIES (ca. 8:30 - 10 p.m.): a series of short reports with discussion. The reports should deal with subject matter of wide interest to Renaissance and Reformation scholars: e.g. a projected index of emblems, the Erasmus project, developments at the Sherbrooke Centre, the Renaissance undergraduate program at UWO etc.

May 24 , morning. SESSION III (2-1/2 - 3 hrs.): THE REFORMATION (Chairman: Gerald Hobbs, Vancouver School of Theology, 6000 Iona Dr., Vancouver). Speakers still to be arranged.

Luncheon meeting of the Executive Committee of the Society.

Afternoon: free. Visits to Stratford can be arranged, we hope, for those interested.

May 24 , ca. 7 p.m. Banquet, followed by a concert of Renaissance music.

May 24, 9 p.m. One hour meeting of the editorial board of Renaissance and Reformation/Renaissance et Réforme. 
May 25, morning. SESSION IV: Joint Session with the Humanities Association of Canada (Chairmen: H. Kerpneck, University of Toronto, for the HAC and M. MacKinnon, University of Guelph, for the CSRS/SCER. Two invited distinguished speakers on Renaissance subjects of wide interest, one in French, the other in English.

May 25, afternoon. SESSION V (1-1/2 hrs.): Panel organized by the University of Western Ontario on "Mannerism: The Phenomenon and the Problem of its Historical Determination." Participants will include: W.S.A. Dale, R.W. McKaskell, A. Santosuosso and perhaps a fourth speaker.

Business Meeting: Following the report of the Nominating Committee (Chairman: H. Secor, Department of French, University of Toronto), a new President and Executive of the Society will be elected. Other business. 